\title{
GENDER DIFFERENCES IN ECONOMIC EXPERIMENTS
}

\section{DIFERENCIAS DE GÉNERO ENLOS EXPERIMENTOSECONÓMICOS}

\author{
Selim JüRgen ERgun sergun@metu.edu.tr \\ Middle East Technical University, Northern Cyprus Campus.
}

\section{Teresa GarcíA-Muñoz tgarciam@ugr.es}

Universidad de Granada. Granada Lab of Behavioral Economics (GLOBE)

\author{
María Fernanda Rivas rivas@metu.edu.tr \\ Middle East Technical University, Northern Cyprus Campus.
}

\begin{abstract}
This paper reviews the experimental economics literature on gender differences concerning four salient subjects: risk aversion, trust, deception and leadership. We review both experiments conducted in a laboratory and field experiments. We summarize very briefly the main characteristics of the experiments we review and point out the main results related to gender differences. The vast majority of the articles we have revised document gender differences in behavior; differences which could be explained by sex-role stereotypes which could be formed even in early stages of life and/or hormonal differences such as the female hormone oxytocin or estrogen.
\end{abstract}

\section{KEYWORDS}

Deception; Economic experiment; Gender; Leadership; Reciprocity; Risk aversion; Trust.

\section{RESUMEN}

Este artículo revisa la literatura en el área de economía experimental sobre las diferencias de género en cuatro temas destacados: aversión al riesgo, confianza, engaño y liderazgo. Se revisan tanto experimentos realizados en laboratorios como experimentos de campo. Resumimos brevemente las principales características de los experimentos que consideramos y señalamos los principales resultados relacionados con las diferencias de género. La gran mayoría de los artículos que hemos revisado documentan diferencias de género en el comportamiento. Estas diferencias podrían explicarse por los estereotipos de roles sexuales que podrian formarse incluso en edades tempranas $\mathrm{y} / \mathrm{o}$ diferencias hormonales como la hormona femenina oxitocina, o el estrógeno.

\section{Palabras Clave}

Confianza; Engaño; Experimento económico; Género; Liderazgo; Reciprocidad. 


\section{INTRODUCTION}

Decades of research in experimental economics has shown that the preferences of individuals and their economic behavior are quite heterogeneous. The literature has attempted to explain this heterogeneity as being due to different factors such as age, education, cultural differences, income levels and social status, among others. One of the most important factors that has been analyzed thoroughly is the role of gender in economic behavior. Gender differences have been analyzed experimentally in many different areas of economics and under very different settings. Recent surveys which review the literature on gender differences in experimental economics focus on different subjects, among them Croson and Gneezy (2009), Eckel and Grossman (2008) and Frank and Lambsdorff (2011).

Croson and Gneezy (2009) review experiments dealing with gender differences in risk, social and competitive preferences. Analyzing a large string of experiments, they observe that, in general, women are more risk averse than men, are more sensitive to social cues and have a lower preference for competitive environments. On the other hand, Eckel and Grossman (2008) review economic experiments that explore gender differences in the behavior of subjects in public goods, dictator and ultimatum games, observing no significant gender differences in behavior when subjects are exposed to risk. In the absence of risk, however, they do observe systematic gender differences, with women taking more socially-oriented decisions. Frank and Lambsdorff (2011) revise the literature of corruption experiments that focus on gender effects. Their main observation is that when women are engaged in a corrupt transaction, this transaction is more likely to fail not because women are more honest, but because they behave more opportunistically when there is a possibility of breaking an implicit corrupt contract.

Our review focuses on four subjects: gender differences in risk aversion, trust, deception and leadership. Risk aversion and trust are probably two of the most widely-studied issues in experimental economics and constitute the fundamental elements of analysis in a vast number of economic experiments. For instance, trust plays a key role in experiments on deception. When a subject can potentially deceive his partner(s), the behavior of the partner(s) will depend on whether they trust the subject or not. As regards leadership, Gillespie and Mann (2004) show that trust influences satisfaction with leaders and their perceived effectiveness.

Economic experiments on deception have become one of the most salient issues in the last decade, while the analysis of gender differences has begun to gain greater attention in this specific literature. For this reason, we focus on gender differences in deception experiments in our review.

Leadership is yet another salient issue in experimental economics. The effectiveness of managers is related to their ability to make decisions (Johnson and Powell 1994). Because managers must often make decisions in uncertain environments, managers' risk aversion affects their decision-making ability. While the ability of a manager to take effective decisions largely determines the success of a firm, the propensity to take risks 
may or may not be desirable depending on the circumstances. Gender differences in decision-making or risk-taking behavior among men and women have consequences for organizations. Although there is a considerable amount of literature on this subject which focuses on gender differences, the experiments dealing with this issue have not been thoroughly revised. Thus, this is another aim of our paper.

This paper reviews evidence on gender difference in risk aversion, trust, deception and leadership. The results are discussed in the final section.

\section{GeNDER DIFFERENCES IN RISK AVERSION}

Under different environments and tasks, the majority of studies about gender differences in risk taking report the same conclusion: women are more risk averse than men (see Croson and Gneezy 2009, Table 1 for a review of the literature). However, several authors argue that this finding is specific to certain contexts. For example, Schubert, Brown, Gysler and Brachinger (1999) found that in a strongly ambiguous context, women are more risk averse where lotteries are framed as gains, while men are more risk averse when lotteries are framed as losses. They find no gender differences when the context is abstract or weakly ambiguous.

Explanations for gender differences are chiefly grounded in two theories: evolution and socialization. Evolutionary arguments hold that sex differences are dependent on reproduction (biology): men are more risk taking in the period when they are trying to attract mates, while women are more risk averse in the child-bearing period (Wood and Eagly 2002). Works that support this theory include those by Brody (1993), Niederle and Vesterlund (2007), Soll and Klayman (2004) and Gysler, Brown-Kruse and Schubert (2002), among others.

Brody (1993) affirms that in anticipation of negative outcomes, women report more nervousness and fear than men, thus it is logical that women are more risk averse when facing a risky situation. Niederle and Vesterlund (2007) and Soll and Klayman (2004) have found that men are more overconfident than women. Thus, men have higher perceptions of the likelihood of a successful outcome in the gamble, and will be more likely to take the gamble. Gysler et al. (2002) explore investment decisions controlling for knowledge of financial markets and an overconfidence test. They found that when knowledge and overconfidence are controlled for, women do not exhibit higher risk aversion. Chen, Katuscak and Ozdenorem (2005) explore gender issues in first and second-price auctions. They find that women bid more aggressively in the first case but they cannot support any gender bias in the second case. They find biological proof for women's behaviour: in the first-price auction, differences among women and men playing experimental auctions disappear when women are menstruating (when the estrogens level is lowest). The gender difference appears in other phases of the menstrual cycle. Brañas-Garza and Rustichini (2011) study the correlation between the ratio of the second to the fourth finger (2D:4D digit ratio), a marker indicating early exposure to testosterone, and risk aversion. For male subjects they 
find that the correlation is positive and significant, however, for female the correlation is not significant.

The socialization theory is not wholly focused on biology, but on cultural and social practices. Because men and women tend to have different social roles, they become psychologically different to adjust to their social roles (Eagly and Wood 1999). Meier-Pesti and Penz's paper (2008) support this theory. They affirm that, regardless of biological sex, risk aversion is associated with feminine attributes. For both sexes, higher scores on femininity (measured through gender identification and sex role tests) reduce the tendency to take risk. Eckel and Grossman (2002) argue that if women are stereotyped as more risk averse, this could affect them negatively in many aspects ranging from lower wages to less aggressive health treatments.

Several studies have shown that gender differences are attenuated by experience and profession. Using a sample of mutual fund managers, Atkinson, Baird and Frye (2003) found no gender differences in the way funds are managed in terms of performance and risk. Examining this same topic, Johnson and Powell (1994:129) found differences among the non-managerial population, but did not observe such differences in the managerial population (managers and potential managers with management education). They study the betting behaviour (on horses and dogs) observed in betting offices throughout the UK, claiming that this is "a real decision made in a natural environment" The subjects involved did not know that their behaviour was being observed. In this subject pool they found that men are more risk taking than women. In the managerial population, the subjects were asked to evaluate a project financially and decide whether or not to recommend it. In this subgroup no gender difference in risk taking was observed.

\section{GENDER DIFFERENCES IN TRUST AND RECIPROCITY}

Behaviour in trust games has been linked to general notions of trust and trustworthiness. A review of studies on gender differences in trust and reciprocity shows contradictory results. In the standard trust game one of the two players, the sender, decides how much money (if any) to send to the other player, the receiver. The experimenter then triples the amount sent and the receiver has to decide how much of the received amount (if any) to send back to the sender. Considering the amount sent as a measure of trusting behaviour, the majority of studies found that men are more trusting than women, while only one found no gender differences and few of them show that women are more trusting than men (see Croson and Gneezy 2009, Table 3). However, the fact that women send the same amount or less than men can be attributed either to lower trust or to higher risk aversion. With respect to reciprocity, the results generally find that women are more reciprocal than men or that there are no gender differences but there exist studies with the opposite result, for instance, using a Latin American sample, Brañas-Garza, Cardenas and Rossi (2009) find that males are more generous than females. 
These contradictory results can be explained by the fact that women are more sensitive to what happens in the experiment. In both trust and reciprocal decisions, small differences in the experimental design affect female participants more than male ones. Buchan, Croson and Solnick (2008) find more variability in female behaviour. For example, if the counterpart is identified in the experiment, the amounts women send vary more than the amounts men send.

Some studies consider the question "Do men and women trust men or women more?" that is, "Does the information about partner's gender influence trust and reciprocity?" The answer to this question is not clear. Eckel and Grossman (2001) and Garbarino and Slonim (2009) found that both women and men trust women more than men, whereas Buchan et al. (2008) did not find differences across gender. Bonein and Serra (2009) observed that participants did not discriminate in their trust behaviour based on the gender of their counterpart, but with regard to reciprocity: the proportion returned is significantly larger when the trustor and the trustee are of the same gender. This type of information could be useful in achieving the highest efficiency between the members of a team and its leader.

\section{GeNDER DIFFERENCES IN DECEPTION}

In recent years, the analysis of gender differences in deception and lying behavior has drawn the attention of researchers in economics. Experiments where subjects are given the possibility to lie or engage in cheap talk have become increasingly popular. A string of research focusing on gender differences in deception follows the work of Gneezy (2005). In Gneezy's experiment, subjects play in pairs where one player is the sender and the other the receiver. The receiver must choose between options $A$ and $B$ where each option has different monetary pay-offs associated to it. One option yields a higher pay-off to the sender than to the receiver, while under the other option it is the receiver who earns more than the sender. These monetary pay-offs are known only by the sender. The sender can send one of two possible messages to the receiver: 1) "Option A will earn you more money than option B"; or 2) "Option B will earn you more money than option A". One message is true and the other message is a lie. After receiving the message, the receiver has to choose one of the two options. Subjects are paid according to the option they choose. Dreber and Johannesson (2008) replicate this experiment to investigate gender differences in behavior, finding that men are significantly more likely than women to lie to obtain a higher monetary benefit. Regarding trust, however, they did not find any significant differences in gender. The fractions of individuals that follow messages from men or women were not statistically different either.

Kristinsson, Arnardóttir and Gylfason (2009) also used the same design to analyze the impact of personality on behavior in the deception game. Contrary to Dreber and Johannesson (2008), however, they found no gender differences in lying.

McGuire (2009) extended upon Gneezy's design (2005) to include a third option and a third message. The third message could be defined as a "big lie". Half of the subjects 
play the Gneezy game (2005), whereas the other half plays the game with three possible messages. The first two options are comparable to the options in the original design. In contrast to the option that is more beneficial to the sender in the original design, the third option would slightly increase the sender's pay-off, while considerably decreasing the receiver's pay-off. The main result McGuire obtains is that only women were made less averse to lying due to the existence of the big lie. That is, the potential of the big lie had little effect on men partly because men lied more often than women when there were only two options. Subjects also had to answer a survey question where they faced a very similar situation to the actual experiment. Both men and women felt that a small lie was less unfair when a big lie was also possible.

Tilley, George and Marett (2005) analyzed gender differences in both deception and the detection of deception in a job interview setting. In their experiments, subjects were assigned one of two roles: interviewer or job applicant. All of the subjects were asked to bring their résumés to the experiment. The résumés of the subjects assigned the role of job applicant were then modified and improved upon by the experimenters. In the interview, the job applicants had to use the résumé that included lies. The interviews were conducted in one of the following four manners: by e-mail, Internet Relay Chat (IRC), IRC with audio, or audio only over IRC. They found that there was a statistically significant difference in deception detection, with women being better at detection than men. Their interpretation is that females may be more attentive to the communication process and thus would be able to observe more cues. However, significant differences were not found across genders in terms of successful deception.

Erat and Gneezy (2009) classify lies into three categories: "selfish black lies", which would harm the receiver but benefit the sender; "altruistic white lies" that would harm the sender but help the receiver; and "Pareto improving white lies", which would increase the monetary pay-offs of both players. As Dreber and Johannesson (2008), they found that men are significantly more likely to tell a selfish black lie. In contrast, women are more likely than men to tell an altruistic white lie, but less likely to tell a Pareto white lie.

Jamison, Karlan and Schechter (2008) analyzed the effect of deception employed by experimenters on subjects. It is a common agreement among economics scholars that subjects should not be deceived as they are a public good for all researchers and deceiving them today would affect their future actions in other experiments and also their decision to participate in them. In Jamison et al. (2008), experimental subjects played the standard trust game. Some of the subjects played the game without any deception, whereas the others were deceived regarding the identity of their partner. They were told that they were playing with another student when in reality they were playing with a computer. After the experiment, the deceived subjects were told the truth. Three weeks after this experiment all the participants in the experiment were invited to another experiment run by another researcher. When comparing the return rate of the deceived and non-deceived subjects, they found that gender differences 
played an important role. The females who had been deceived were significantly less likely to participate in another experiment, whereas the men were significantly more likely to return.

The existence of cheap talk can give a person the possibility to lie to another person if it is in his/her interest to do so. Lundquist, Ellingsen, Gribbe and Johannesson (2009) focused on the effect of cheap talk in a bargaining game. In this experiment, one of the two parts, the seller, has confidential information about his/her own skill. The level of skills is determined by a test measuring general knowledge. The seller can send a written message to the other player, the buyer, regarding his/her own level of skills. After receiving the message, the buyer decides whether to offer the seller a fixed-payment contract or not. The buyer only obtains a positive benefit from the contract if the seller's level of skills is above a certain threshold. Thus, sellers with a level of skills that is lower than the threshold have incentives to lie. Seventy percent of the sellers had a skill level below the threshold. The authors compared four treatments: one without cheap talk, one with free-form communication and two treatments with pre-specified communication. Regarding the effect of gender, they found that although women are less likely to lie than men, the difference is not statistically significant.

\section{GENDER DIFFERENCES IN LEADERSHIP}

Many papers have found evidence of differences in leadership styles between men and women. Chattapadhyayvand and Duflo (2004) found differences in the investment policy of female and male policymakers in village councils of West Bengal and Rajasthan, India where one-third of these councils must be headed by women since the mid-1990s. They compared the councils headed by women with those led by men. Women were found to invest more in public goods linked to women's concerns (drinking water, etc.) and invest less in public goods linked to men's concerns (education, etc.), i.e. women leaders increase the provision of public goods that benefit women. Their findings suggest that the gender of politicians influences policy decisions; a factor that might play an important role when assigning scarce economic resources, especially in developing countries. Moreover, Duflo (2005) shows that there is a positive relationship between economic development and women's empowerment.

As regards the acceptance of female leaders in a related context, King and Matland (2003) studied the effect of the gender of a Republican candidate on the electorate. They find that the candidate's gender affects the possibility of being voted for, but the effect depends on the party affiliation of the voters. Being a female Republican candidate has a positive effect (in comparison to a male Republican candidate) among Democrats and Independents, but a negative effect among Republican voters.

These papers, among others, suggest that it is important to study the relationship between leadership and gender. 
In an experiment with 288 first-year cadets at the US Military Academy, Rice, Bender, and Vitters (1980) studied the impact of the leader's gender on group performance and followers' morale. Half of the groups had a male leader and half a female leader. All the followers were men (due to the scarcity of female cadets). Considering all the followers, they did not observe a strong negative bias in terms of the (male) followers evaluation of the female leaders. However, they did find differences when separating the groups between those whose followers held traditional views towards women and those with more liberal views. While the former evaluate female leaders worse than male leaders, the latter do the opposite.

In an economic experiment, Grossman and Komai (2008) examined whether there is a difference in leader's and follower's behavior across gender. In their public goods experiment, subjects interact in groups of three members, where the leader has precise information about the marginal return of the public good and the followers do not. The followers only know that there are three possible scenarios: Scenarios 1 and 2 , where it is socially beneficial to contribute to the public good; and Scenario 3, where there is no incentive to contribute (either from an individual or a social point of view). Although in Scenario 2 contributing is socially beneficial and free riding is a strictly dominant strategy, in Scenario 1 it is not. They conducted two treatments: one where the leader's gender is disclosed and one where it is not. They found a positive and significant relationship between the followers' and leaders' contributions, but did not find a significant correlation between the followers' decision and their gender and the leader's gender. What they did find is that the decisions made by female leaders are influenced by the treatment, whereas the males' decisions are not: women contribute less to the public good in the treatment where their gender is disclosed to the followers. Grossman and Komai's interpretation is that female leaders expect followers to contribute less when they know their gender than when they do not. This behavior is observed in Scenario 2 where the leader's payoff depends strongly on the followers' contributions.

Arbak and Villeval (2007) analyzed the willingness of subjects to lead their group despite the fact that doing so will be costly for them. They found that males are more enthusiastic about leading than females, but this difference vanishes when attributes (gender and the amount the subject has donated to a charity at the beginning of the experiment) are disclosed. Arbak and Villeval's interpretation is that women need more information than men about their group members to be willing to lead (where leading is costly for them).

Kocher, Pogrebna and Sutter (2008) studied leadership through an experiment where subjects play in groups of three members and where they have to choose between two lotteries that they would like to play as a group. The leaders observe the decisions of the other members of the group, but can choose the type of lottery they prefer, considering or ignoring the other members' preferences. They found that women are more likely to take into account the other members' preferences than men do, i.e. men are more prone to overrule the team than women. Therefore, given that 
women tend to take into account the opinion of the other members of their team, they conclude that when organizations have a team-oriented philosophy of decision making, it would be convenient to promote female leaders. Chaganti (1986:28) (reviewed in Johnson and Powell 1994) found that female entrepreneurs "seem to prefer a more people-orientated and less autocratic management style,... their managerial styles in particular may be more feminine".

\section{Discussion}

For several decades, researchers in the area of leadership have distinguished two types of behaviour: agentic, task-oriented behaviour versus communal, social-oriented behaviour (Berdahl 1996). This distinction runs parallel to the attributes traditionaIly associated with masculinity and feminity: agenticism (agenticism includes being assertive, controlling, ambitious, dominant, independent, self-confident and competitive, among others) and communalism (communalism includes being concerned with caring, emotional, empathetic and supportive, among others), respectively. However, there is emerging evidence that women leaders may be more likely to ignore rules and take more risks than men (Greenberg and Sweeney 2005). Johnson and Powell (1994) review papers which suggest that risk taking differences between males and females might be influenced by the fact that such behavior is negatively valued in women and therefore women who take risks are unpopular. In contrast, the opposite is true for men as risk taking behaviour is viewed as a positive attribute and is culturally reinforced in males. Slovic (1966) showed that gender differences are observed once the children follow their expected sex-role stereotype. In spite of this and also the fact that women are evaluated negatively when they behave inconsistently with their sex role (Eagly, Wood and Dickman 2000), some women leaders are not bound by conventional wisdom and are willing to take risks.

Recently, gender differences have been studied by neurobiology researchers. Their findings could explain the differences found in experimental economics. At the country level, Zack and Fakhar (2009) found that interpersonal trust may be related to the intake of neuroactive hormones. They found that consumption of estrogens and their presence in the environment are related to trust. This may partially explain gender differences in social behaviors. Moreover, research supports the existence of differences in leadership styles between men and women. Nowack (2009) suggests that this difference may be due to at least one female hormone called oxytocin, which may affect the way women react under stress and explain why women do indeed lead differently than men. Barraza and Zak (2009) show that empathy, trust and collaboration is boosted by oxytocin. Based on these findings, Nowack (2009) concludes that the gender difference due to oxytocin might contribute to explaining the observed tendency among females to lead in a more participatory manner and to promote socially oriented behavior such as cooperation, team work and assisting co-workers. 


\section{REFERENCES}

Arbak, E. and M.C. Villeval. 2007. "Endogenous leadership. Selection and influence." IZA Discussion Papers 2732. Institute for the Study of Labor (IZA). Bonn.

Atkinson, S. M., S.B. Baird and M.B. Frye. 2003. "Do female mutual fund managers manage differently?." Journal of Financial Research 26(1):1-18.

Barraza, J. and P. Zak. 2009. "Empathy towards strangers triggers oxytocin release and subsequent generosity." Annals of the New York Academy of Sciences 1167:182-189.

Berdahl, J. L. 1996. "Gender and leadership in work groups: Six alternative models." Leadership Quartely 7(1): 21-40.

Bonein, A. and D. Serra. 2009. "Gender pairing bias in trustworthiness." The Journal of Socio-Economics 38: 779-789.

Brañas-Garza, P., J.C. Cardenas and M. Rossi. 2009. "Gender, education and reciprocal generosity: Evidence from 1500 experiment subjects." ECINEQ WP 2009-128. Society for the Study of Economic Inequality.

Brañas-Garza, P. and A. Rustichini. 2011. "Organizing effects of testosterone and economic behavior: not just risk taking." Plos One 6(12): e29842. doi:10.1371/journal.pone.0029842.

Brody, L. R. 1993. "On understanding gender differences in the expression of emotions." Pp. 87-121 in Human Feeling: Explorations in Affect Development and Meaning. ed. S. L. Ablon, D. Brown, E. J. Khantzian and J. E. Mack., Hillsdale. N.J.: Analytic Press.

Buchan, N. R., R. Croson and S.J. Solnick. 2008. "Trust and gender: an examination of behavior and beliefs in the investment game." Journal of Economic Behavior and Organization 68(3-4): 466-476.

Chaganti, R. 1986. "Management in women-owned enterprises." Journal of Small Business Management 24(4):18-29.

Chattapadhyayvand, R., and E. Duflo. 2004. "Women as policy makers: evidence from a randomized policy experiment in India." Econometrica 72(5):1409-1443.

Chen, Y., P. Katuscak and E. Ozdenorem. 2005. "Why can't a woman bid more like a man?" CERGE-EI WP 275. Center for Economic Research and Graduate Education. Prague.

Croson, R. and U. Gneezy. 2009. "Gender differences in preferences." Journal of Economic Literature 47(2): 1-27.

Dreber, A. and M. Johannesson. 2008. "Gender differences in deception." Economics Letters 99(1): 197-199.

Duflo, E. 2005. "Gender equality in development." BREAD Policy Paper No. 001. Bureau for Research in Economic Analysis of Development.

Eagly, A. and W. Wood. 1999. "The origins of sex differences in human behavior: evolved dispositions versus social roles." American Psychologist 54: 408-423. 
Eagly, A., W. Wood and A.B. Dickman. 2000. "Social role theory of sex differences and similarities: a current appraisal." Pp. 123-174 in The developmental social psychology of gender, edited by T. Eckes and H. M. Trautne. Mahwah, NJ: Erlbaum.

Eckel, C. C. and P.J. Grossman. 2001. "Chivalry and solidarity in Ultimatum Games." Economic Inquiry 39(2):171-188.

Eckel, C. C. and P.J. Grossman. 2002. "Sex differences and statistical stereotyping in attitudes toward financial risk." Evolution and Human Behavior 23(4): 281-295.

Eckel, C. C. and P.J. Grossman. 2008. "Differences in the economic decisions of men and women: experimental evidence." Pp. 509-519 in Handbook of Experimental Economics Results, Volume 1, edited by C. Plott and V. Smith. New York: Elsevier.

Erat, S. and U. Gneezy. 2009. "White lies." Rady School of Management, USCD Woricing Paper.

Frank, B. and J. Lambsdorff. 2011. "Gender and corruption: lessons from laboratory corruption experiments." European Journal of Development Research 23(1): 59-71.

Garbarino, E. and R. Slonim. 2009. "The robustness of trust and reciprocity across a heterogeneous U.S. population." Journal of Economic Behavior and Organization 69(3): 226-240.

Gillespie, N. A. and L. Mann. 2004. "Transformational leadership and shared values: the building blocks of trust." Journal of Managerial Psychology 19:588-607.

Gneezy, U. 2005. "Deception: the role of consequences." American Economic Review 95: 384-394.

Greenberg, H. and P. Sweeney. 2005. "Leadership: Qualities that distinguish women." Financial Executive: $32-36$.

Grossman, P. J. and M. Komai. 2008. "Leadership and gender." Working Papers from Saint Cloud State University No 2008-04. Department of Economics. Minnesota.

Gysler, M., J. Brown-Kruse and R. Schubert. 2002. "Ambiguity and gender differences in financial decision making: an experimental examination of competence and confidence effects." Research Working Paper 02-23. Swiss Federal Institute of Technology. Zurich.

Jamison, J., D. Karlan and L. Schechter. 2008. „To deceive or not to deceive: the effect of deception on behaviour in future laboratory experiments." Journal of Economic Behavior and Organization 68: 477-488.

Johnson, J. E. and P.L. Powell. 1994. "Decision making, risk and gender: are managers different?" British Journal of Management 5(2): 123-138.

King, D. C. and R.E. Matland. 2003. "Sex and the grand old party. An experimental investigation of the effect of candidate sex on support for a Republican candidate." American Politics Research 31(6): 595-612.

Kocher, M. G., G. Pogrebna and M. Sutter. 2008. "The Determinants of Managerial Decisions Under Risk." Working Papers in Economics and Statistics 2008/04. 
Kristinsson, K., A. Arnardóttir and H.F. Gylfason. 2009. "The impact of personality on dishonest behavior in cheap talk game." http://nordicconference.org/wp-content/uploads/2009/10/Kristinsson.pdf. Consultado el 13 de diciembre de 2010.

Lundquist, T., T. Ellingsen, E. Gribbe and M. Johannesson. 2009. "The aversion to lying." Journal of Economic Behavior and Organization 70:81-92.

McGuire, J. 2009. "The impact of alternatives on honesty: testing for violations of WARP and/or convexity." http://www.stanford.edu/ jcmir/McGuireJobMarketPaper.pdf. Consultado el 24 de Noviembre de 2010.

Meier-Pesti, K. and E. Penz. 2008. "Sex or gender? Expanding the sex-bases view by introducing masculinity and femininity as predictor of financial risk taking." Journal of Economic Psychology 29(2):180-196.

Niederle, M. and L. Vesterlund. 2007. "Do women shy away from competition? Do men compete too much?" Quarterly Journal of Economics 122(3):1067-1101.

Nowack, K. 2009. "The neurobiology of leadership: why women lead differently than men." Paper presented at the Life09 I Congreso Internacional de Liderazgo Femenino. Barcelona. Spain.

Rice, R. W., L.R. Bender and A.G. Vitters. 1980. "Leader sex, follower attitudes toward women, and leadership effectiveness: a laboratory experiment." Organizational Behavior and Human Performance 25:46-78.

Schubert, R., M. Brown, M. Gysler and H.W. Brachinger. 1999. "Financial decision-making: are women really more risk-averse?" American Economic Review 89(2):381-385.

Slovic, P. 1966. "Risk taking in children: age and sex differences." Child Development 37(1): 169-176.

Soll, J. B. and J. Klayman. 2004. "Overconfidence in interval estimates." Journal of Experimental Psychology: Learning, Memory and Cognition 30(2):299-314.

Tiller, P., J. George and K. Marett. 2005. "Gender differences in deception and its detection under varying electronic media conditions." Proceedings of the 38th Hawaii International Conference on System Sciences.

Wood, W. and A. Eagly. 2002. "A cross-cultural analysis of the behavior of women and men: implications for the origins of sex differences." Psychological Bulletin 128: 699-727.

Zack, P. J. and A. Fakhar. 2009. "Neuroactive hormones and interpersonal trust: international evidence." Economics and Human Biology 4:412-429.

SeLIM JÜRGEN ERgun holds a BS in Electrical and Electronics Engineering from Bilkent University (Turkey), a Masters degree in Economics from Sabanci University (Turkey) and a PhD in Economic Analysis from the Universitat Autónoma de Barcelona (Spain). He is an Assistant Professor in the Economics Program at Middle East Technical University - Northern Cyprus Campus. His research interests include Public Economics, Political Economy, and Experimental Economics. 
Teresa García-Muñoz is Associate Professor of Econometrics at Universidad de Granada (Spain). Her research interests include experimental economics, decision making, gender and economics of religion. She has published her research in Journal of Behavioral Decision Making, Judgment and Decision Making, Journal of Population Economics, International Journal of Social Welfare, Cuadernos Económicos de ICE, and Applied Mathematics and Computation.

María Fernanda Rivas holds a BA in Economics from the Universidad de la República (Uruguay) and a PhD in Economic Analysis from the Universitat Autonoma de Barcelona (Spain). She is an Assistant Professor in the Economics Program at Middle East Technical University - Northern Cyprus Campus. Her research interests include Experimental Economics, Behavioral Economics, and Applied Microeconomics.

RECEIVED: 19 April 2011

ACCEPTED: 8 December 2011 